\title{
DATA WAREHOUSE DAN DATA MINING PENDIDIKAN TINGGI: STUDI KASUS KATEGORI UNDUR DIRI DI UNIVERSITAS BINA NUSANTARA
}

\author{
Sulistyo Heripracoyo \\ Information Systems Department, School of Information Systems, Binus University \\ Jl. K.H. Syahdan No. 9, Palmerah, Jakarta Barat 11480 \\ hpracoyo@binus.edu
}

\begin{abstract}
Data warehouse and data mining is used to extract useful information and has a specific meaning and to develop a real relationship between some variables stored in the data/data warehouse. A data warehouse is appropriately designed and added a requirement to provide appropriate data and is useful in making better decisions. Hardware and software facilitate adequate access to such data, analyze and display the results interactively. Data mining software is a highly effective tool that can be used to interrogate the data contained in the data warehouse in order to find a relationship (Neary 1999). This study conducts some literature studies applies some models and case studies in a higher education institution, in terms of the benefits, functions and development. The case study conducted is objected to see the trend and prediction of the number of students who drop out (DO).
\end{abstract}

Keywords: data warehouse, data mining, prediction, drop out

\begin{abstract}
ABSTRAK
Data warehouse dan data mining dipergunakan untuk mengektraksi informasi yang bermanfaat dan mempunyai arti tertentu serta untuk mengembangkan suatu hubungan yang nyata di antara beberapa variabel yang tersimpan di dalam data. Suatu data warehouse yang dirancang dan ditambahkan dengan tepat dapat memberikan suatu kebutuhan data yang sesuai dan berguna pada pengambilan keputusan yang lebih baik. Bantuan perangkat keras dan perangkat lunak yang memadai memudahkan akses terhadap data tersebut, menganalisis dan menampilkan hasilnya secara interaktif. Perangkat lunak data mining merupakan piranti yang sangat efektif yang dapat dipergunakan untuk menginterogasi jumlah data yang terkandung dalam data warehouse agar dapat menemukan hubungan (Neary 1999). Dalam paper ini akan dilakukan beberapa studi literatur dan menerapkan beberapa model dan studi kasusnya dalam institusi pendidikan tinggi, ditinjau dari manfaat, fungsi dan pengembangannya. Studi kasus yang dilakukan adalah melihat trend dan prediksi dari jumlah mahasiswa yang melakukan undur diri atau drop out (DO).
\end{abstract}

Kata kunci: data warehouse, data mining, prediksi, drop out 


\section{PENDAHULUAN}

Secara sederhana, data warehouse (DW) adalah kumpulan data yang dihasilkan untuk mendukung pengambilan keputusan. Data warehouse adalah suatu repository terpusat dari data histori yang menyediakan suatu platform terintegrasi yang dapat digunakan untuk menganalisis data histori. Menurut Inmon (2002, p31-34), data warehouse mempunyai empat karakteristik yang penting, yaitu: subject-oriented, integrated, nonvolatile dan time-variant. Subject-Oriented adalah data yang ada di dalam data warehouse berorientasi subject, bukan berorientasi pada transaksional (aplikasi). Integrated adalah data di dalam data warehouse berasal dari banyak sumber yang berbeda/terpisah untuk diintegrasikan ke dalam data warehouse. Nonvolatile adalah data di dalam data warehouse hanya dilakukan update secara statis dengan hanya melakukan insert data (snapshot) dan tidak melakukan perubahan/update terhadap data warehouse. Time-variant adalah data di dalam data warehouse hanya akan akurat pada salah satu moment waktu. Lima tahap pengambilan keputusan di dalam data warehouse adalah: reporting (pelaporan), analyzing (menganalisis), predicting (memprediksi), operationalizing (operasionalisasi), dan active warehousing (Stephen Brobst and Joe Rarey (2003) dalam artikelnya Akintola et al., 2011).

Data mining digunakan saat ini terutama oleh perusahaan dengan fokus konsumen yang kuat ritel, organisasi keuangan, komunikasi, dan pemasaran (Akintola et al., 2011). Hal ini memungkinkan perusahaan-perusahaan untuk menentukan hubungan di antara faktor "internal" seperti harga, penempatan produk, atau keterampilan staf, dan faktor "eksternal" seperti indikator ekonomi, persaingan, dan demografi pelanggan. itu memungkinkan mereka untuk menentukan dampak pada penjualan, kepuasan pelanggan, dan keuntungan perusahaan. Dalam prakteknya, tujuan utama data mining cenderung untuk prediction (prediksi) dan description (deskripsi) (Kantardzic (2003, p.2). Prediksi mencakup menggunakan beberapa variabel atau fields dalam data set untuk memprediksi nilai yang tidak diketahui atau nilai kedepan (future) dari variabel yang penting. Deskripsi berfokus pada menemukan pola yang menguraikan data yang dapat diinterpretasikan oleh manusia, yang selanjutnya aktivitas data mining dapat dibagi dua kategori, yaitu predictive data mining yang menghasilkan model dari sistem yang diuraikan dengan data set yang diberikan, atau descriptive data mining yang menghasilkan informasi baru, nontrivial didasarkan pada data set yang tersedia. Tugas (tasks) datamining utama dibagi menjadi beberapa, antara lain: (1) classification - menemukan dari suatu fungsi pembelajaran prediktif yang mengklasifikasi suatu item data ke dalam satu dari beberapa kelas yang didefinisikan sebelumnya; (2) regression - menemukan dari fungsi pembelajaran prediktif, yang memetakan suatu item data ke dalam suatu variable prediksi nilai-nyata; (3) clustering - suatu tugas deskriptif umum di mana salah satu mencari untuk mengidentifikasi suatu set kategori yang terbatas atau cluster untuk menguraikan data tersebut; (4) summarization - suatu tugas deskriptif tambahan yang mencakup metode untuk menempukan suatu deskripsi yang erat untuk suatu set (atau subset) dari data; (5) dependency modeling - menemukan suatu model lokal yang menguraikan dependensi nyata di antara variabel atau di antara nilai dari fitur dalam suatu data set atau dalam suatu bagian dari data set; (6) change and deviation detection - menemukan perubahan paling signifikan dalam data set.

Proses sehari-hari dapat diatasi dengan sistem online transaction processing (OLTP) dengan baik. Akan tetapi sistem OLTP tidak cukup ketika dibutuhkan untuk mendukung keputusan strategis. Kekurangan sistem OLTP adalah bahwa data historis dari OLTP tersebut tidak secara komprehensi dapat mendukung informasi bisnisnya. Tujuan membuat data warehouse dalam pendidikan adalah terutama untuk mengetahui dan menjawab beberapa hal tentang: bagaimana tren penerimaan siswa, pendaftaran mahasiswa, jadwal dosen, jumlah pendaftaran tahunan, dll. Jenis pertanyaan memerlukan banyak data historis untuk menghasilkannya di mana sistem sistem OLTP tidak dapat mendukung. 


\section{METODE}

Dalam studi kasus ini akan dilakukan analisis terhadap jumlah mahasiswa yang melakukan undur diri, drop out (DO) dilihat dari beberapa atribut atau variabel yang terkait, yaitu jenis kelamin, jurusan yang dipilih, jurusan sma, hasil test masuk, jenis pendaftaran, kategori undur diri/DO, grade matakuliah algoritma.

Data operasional atau Online Transaction Processing (OLTP) adalah data transaksi operasional dari hari ke hari untuk proses secara rutin. Dalam penelitian ini data logikal dari proses OLTP dapat dilihat pada Gambar 1.

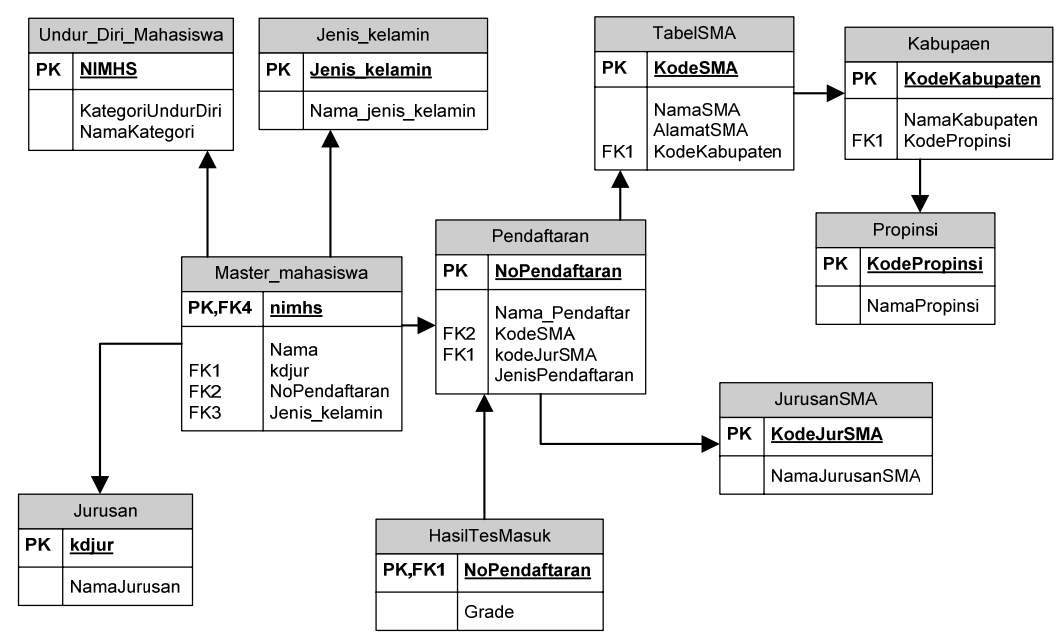

Gambar 1. Data Logikal dari proses OLTP.

Data warehouse umumnya dibuat dengan satu tabel fakta terpusat yang besar, dan beberapa tabel dimensi yang lebih kecil. Konfigurasi ini biasanya disebut dengan skema bintang. Suatu skema bintang digunakan dalam penelitian ini (Gambar 2). Di bawah ini adalah diagram hubungan di antara tabel fakta dan tabel dimensi. Data dari proses OLTP akan dilakukan ETL (Extract, Transform, Load) ke dalam tabel fakta dan dimensi.

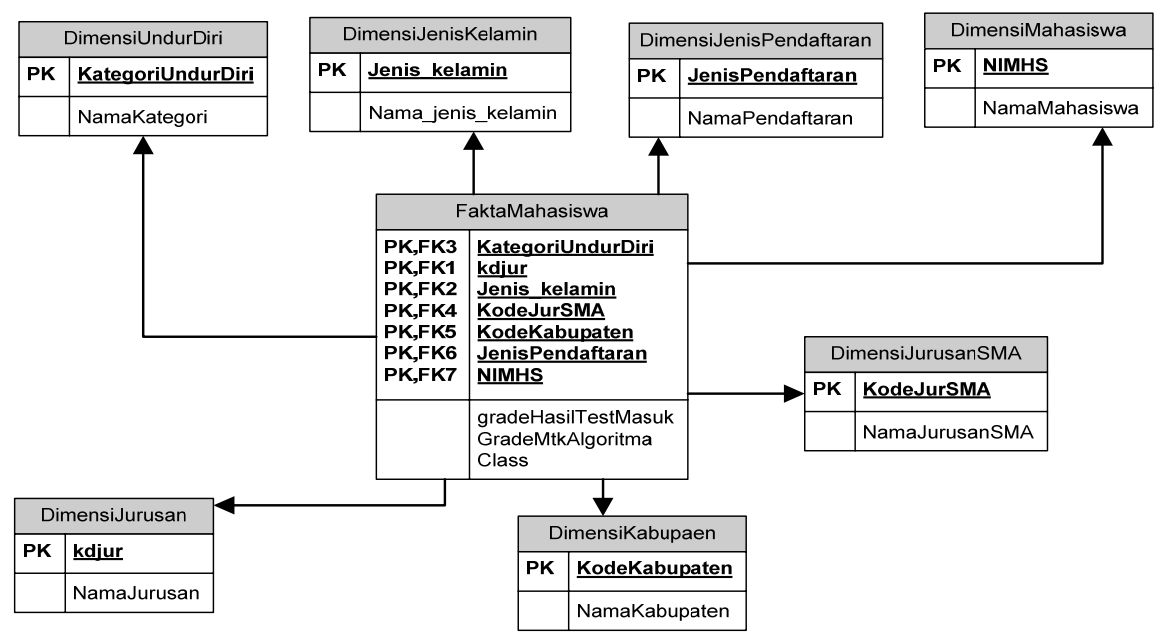

Gambar 2. Skema bintang. 
Dalam studi ini digunakan satu tabel fakta dan tujuh tabel dimensi. Tabel fakta berisi data measure yang berupa grade hasil test masuk dan grade matakuliah algoritma beserta dengan class yang berisi data keterangan tentang proses DO. Dalam studi yang dilakukan jenis class yang ditampilkan adalah sebagai berikut (Tabel 2):

Tabel 2

Keterangan Pengelompokan Class

\begin{tabular}{cll}
$\begin{array}{c}\text { Kategori } \\
\text { Undur Diri }\end{array}$ & Keterangan Kategori & Class \\
\hline 1 & Diberhentikan & Worst \\
\hline 1 & Drop Out (DO) & Worst \\
\hline 1 & PTTKK & Worst \\
\hline 1 & Tidak Lulus SMU & Worst \\
\hline 2 & $\begin{array}{l}\text { Pindah } \\
\text { Jurusan/Jenjang/Renim }\end{array}$ & F-PindahJur \\
\hline 2 & Pindah ke PT Lain & F-PT Lain \\
\hline 2 & Terima UMPTN & F-UMPTN \\
\hline 2 & Undur Diri & Bad-Und \\
\hline 2 & Undur Diri karena DO & Bad-Und \\
\hline 2 & Undur Diri karena Keuangan & Bad-Keu \\
\hline 2 & $\begin{array}{l}\text { Undur Diri Sepihak dari } \\
\text { BINUS }\end{array}$ & Bad-Und \\
\hline
\end{tabular}

Dari pembagian Class dalam Tabel 1 di atas, dapat dijelaskan sebagai berikut, kode undur diri (1) merupakan undur diri dengan kategori DO, Pelanggaran (PTTKK/Peraturan Tata Tertib Kehidupan Kampus), Diberhentikan dan tidak Lulus SMA. Kategori tersebut dimasukkan/dikelompokkan sebagai Worst. Selanjutnya jenis undur diri (2) terbagi lagi menjadi beberapa kategori dengan keterangan karena adanya beberapa hal, antara lain Masalah keuangan (Bad-Keu), Karena undur Diri (Bad-Und), karena diterima di Perguruan Tinggi Negeri (F-UMPTN), pindah ke Pergurutan Tinggi lain (F-PT Lain) dan Pindah ke jurusan lain (F-PindahJur).

Secara Deskriptif data yang digunakan dapat dilihat dari data di bawah ini, data yang digunakan terdiri dari 1396 record, yang meliputi data pada tahun 2005, 2006 dan 2007. Jurusan yang dipilih adalah jurusan yang merupakan mayoritas jurusan yang ada di Binus University, yaitu Jurusan Sistem Informasi, Jurusan Teknik Informatika dan Jurusan Komputerisasi Akuntansi.

\begin{tabular}{|c|c|c|c|c|c|c|c|c|c|c|c|c|}
\hline \multicolumn{7}{|c|}{ Count of nimhs } & \multicolumn{6}{|c|}{ Grade } \\
\hline priod & jnkel & nmjur & kategori & jenis & $\begin{array}{l}\text { grade_m } \\
\text { tk_algo }\end{array}$ & class & ? & A & $\mathrm{B}$ & $\mathrm{C}$ & $\mathrm{D}$ & $\begin{array}{l}\text { Gra } \\
\text { nd } \\
\text { Tot } \\
\text { al }\end{array}$ \\
\hline \multirow[t]{9}{*}{2005} & 1 & $\begin{array}{l}\text { Komputer } \\
\text { isasi } \\
\text { Akuntansi }\end{array}$ & 1 & Diberhentikan & 1 & Worst & & 2 & 12 & 12 & 3 & 29 \\
\hline & & & & & 2 & Worst & & & 2 & 1 & 1 & 4 \\
\hline & & & & Drop Out (DO) & 1 & Worst & & 7 & 8 & 14 & 5 & 34 \\
\hline & & & & Tidak Lulus & & & & & & & & \\
\hline & & & & SMU & $?$ & Worst & & & 1 & & 1 & 2 \\
\hline & & & 1 Total & & & & & 9 & 23 & 27 & 10 & 69 \\
\hline & & & & Pindah ke PT & & F-PT & & & & & & \\
\hline & & & 2 & Lain & $?$ & Lain & & 1 & & & & 1 \\
\hline & & & & Undur Diri & $?$ & $\begin{array}{l}\text { Bad- } \\
\text { Und }\end{array}$ & & & 2 & 4 & & 6 \\
\hline
\end{tabular}




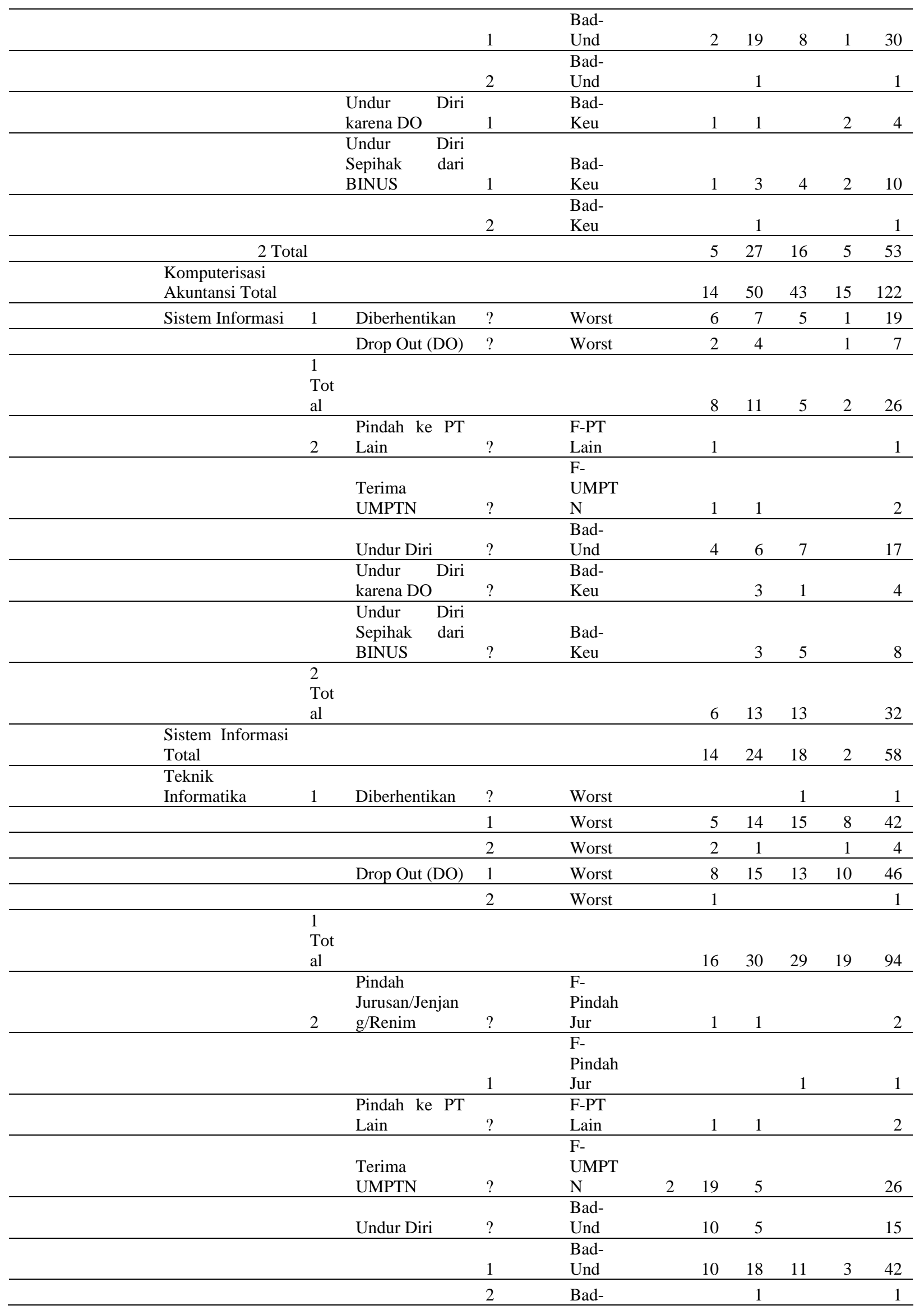




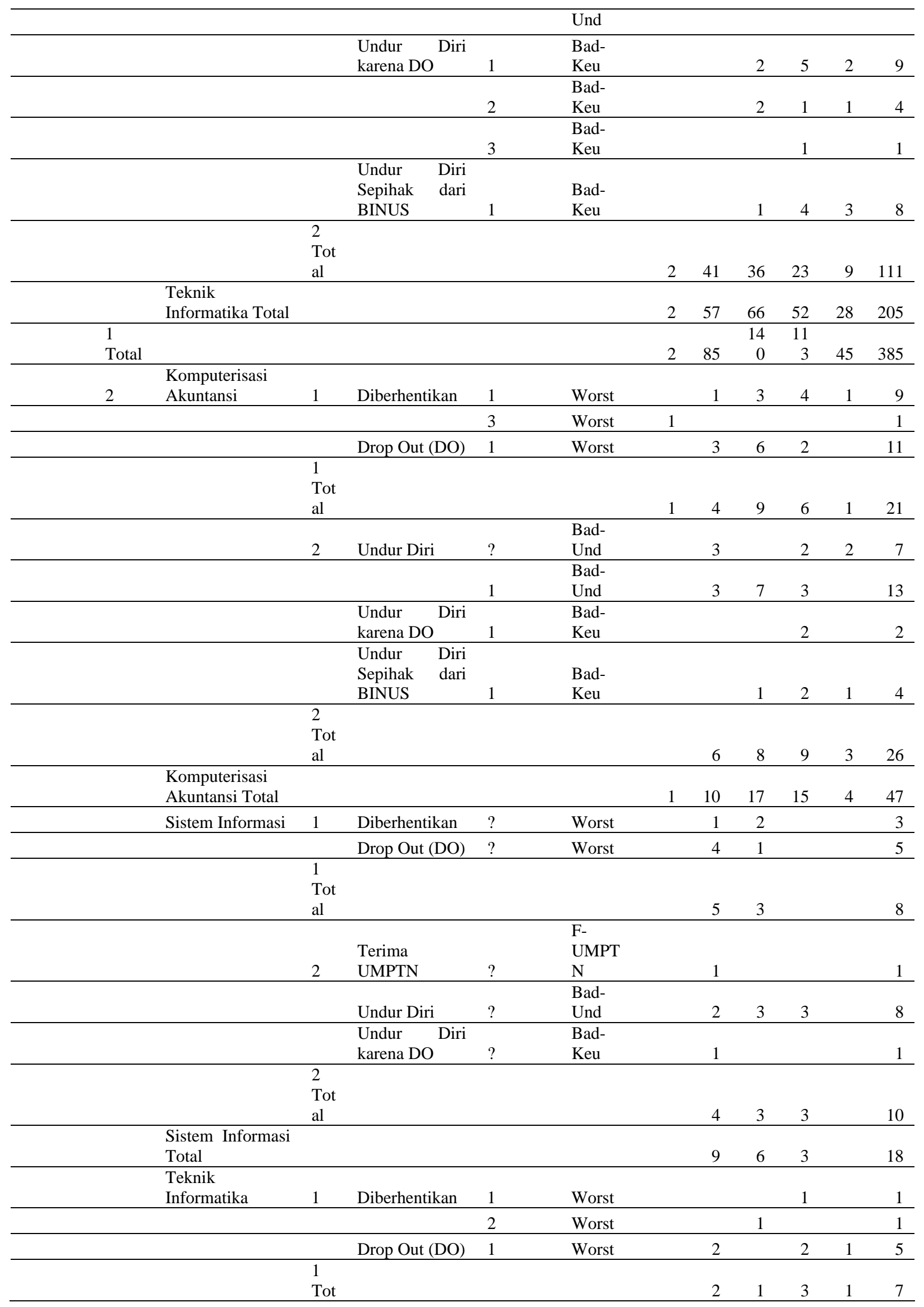




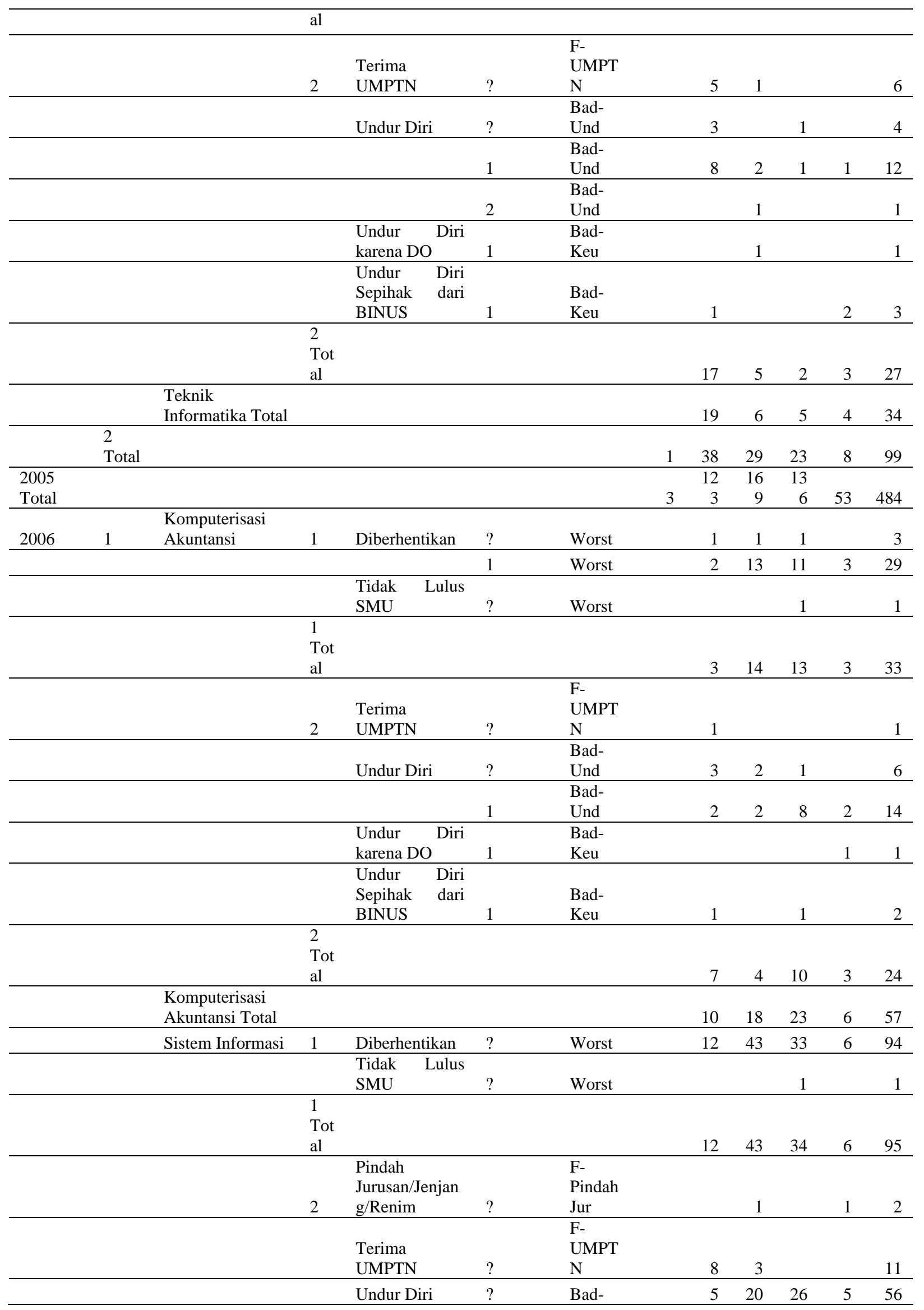




\begin{tabular}{|c|c|c|c|c|c|c|c|c|c|c|c|}
\hline & & & & & Und & & & & & & \\
\hline & & & $\begin{array}{l}\text { Undur Diri } \\
\text { karena DO }\end{array}$ & ? & $\begin{array}{l}\text { Bad- } \\
\text { Keu }\end{array}$ & & 2 & 3 & 2 & 1 & 8 \\
\hline & & & $\begin{array}{ll}\text { Undur } & \text { Diri } \\
\text { Sepihak } & \text { dari } \\
\text { BINUS } & \\
\end{array}$ & ? & $\begin{array}{l}\text { Bad- } \\
\text { Keu }\end{array}$ & & & 2 & 1 & 1 & 4 \\
\hline & & $\begin{array}{l}2 \\
\text { Tot } \\
\text { al } \\
\end{array}$ & & & & & 15 & 29 & 29 & 8 & 81 \\
\hline & $\begin{array}{l}\text { Sistem Informasi } \\
\text { Total }\end{array}$ & & & & & & 27 & 72 & 63 & 14 & 176 \\
\hline & $\begin{array}{l}\text { Teknik } \\
\text { Informatika } \\
\end{array}$ & 1 & Diberhentikan & 1 & Worst & & 6 & 21 & 20 & 10 & 57 \\
\hline & & & & 2 & Worst & & & 3 & & & 3 \\
\hline & & & & 3 & Worst & & 1 & 1 & & & 2 \\
\hline & & & $\begin{array}{ll}\text { Tidak } & \text { Lulus } \\
\text { SMU } & \\
\end{array}$ & $?$ & Worst & & & 2 & & 1 & 3 \\
\hline & & $\begin{array}{l}1 \\
\text { Tot } \\
\text { al }\end{array}$ & & & & & 7 & 27 & 20 & 11 & 65 \\
\hline & & 2 & $\begin{array}{l}\text { Pindah } \\
\text { Jurusan/Jenjan } \\
\text { g/Renim }\end{array}$ & $?$ & $\begin{array}{l}\text { F- } \\
\text { Pindah } \\
\text { Jur } \\
\end{array}$ & & & & 1 & & 1 \\
\hline & & & $\begin{array}{l}\text { Terima } \\
\text { UMPTN }\end{array}$ & ? & $\begin{array}{l}\text { F- } \\
\text { UMPT } \\
\mathrm{N} \\
\end{array}$ & 5 & 38 & 12 & 2 & & 57 \\
\hline & & & & 1 & $\begin{array}{l}\text { F- } \\
\text { UMPT } \\
\mathrm{N} \\
\end{array}$ & & & 2 & & & 2 \\
\hline & & & Undur Diri & ? & $\begin{array}{l}\text { Bad- } \\
\text { Und }\end{array}$ & & 1 & 1 & & 1 & 3 \\
\hline & & & & 1 & $\begin{array}{l}\text { Bad- } \\
\text { Und }\end{array}$ & 2 & 17 & 26 & 19 & 8 & 72 \\
\hline & & & & 2 & $\begin{array}{l}\text { Bad- } \\
\text { Und }\end{array}$ & & 1 & & & & 1 \\
\hline & & & & 3 & $\begin{array}{l}\text { Bad- } \\
\text { Und } \\
\end{array}$ & & 1 & & & & 1 \\
\hline & & & $\begin{array}{l}\text { Undur Diri } \\
\text { karena DO }\end{array}$ & 1 & $\begin{array}{l}\text { Bad- } \\
\text { Keu }\end{array}$ & & 1 & 2 & 4 & 1 & 8 \\
\hline & & & & 2 & $\begin{array}{l}\text { Bad- } \\
\text { Keu }\end{array}$ & & 1 & & & 1 & 2 \\
\hline & & & $\begin{array}{ll}\begin{array}{l}\text { Undur } \\
\text { Sepihak }\end{array} & \text { Diri } \\
\text { BINUS } & \\
\end{array}$ & 1 & $\begin{array}{l}\text { Bad- } \\
\text { Keu }\end{array}$ & & & 1 & & 1 & 2 \\
\hline & & $\begin{array}{l}2 \\
\text { Tot } \\
\text { al }\end{array}$ & & & & 7 & 60 & 44 & 26 & 12 & 149 \\
\hline & $\begin{array}{l}\text { Teknik } \\
\text { Informatika Total }\end{array}$ & & & & & 7 & 67 & 71 & 46 & 23 & 214 \\
\hline $\begin{array}{l}1 \\
\text { Total } \\
\end{array}$ & & & & & & 7 & $\begin{array}{r}10 \\
4 \\
\end{array}$ & $\begin{array}{r}16 \\
1 \\
\end{array}$ & $\begin{array}{r}13 \\
2 \\
\end{array}$ & 43 & 447 \\
\hline 2 & $\begin{array}{l}\text { Komputerisasi } \\
\text { Akuntansi } \\
\end{array}$ & 1 & Diberhentikan & 1 & Worst & & 1 & 2 & 8 & & 11 \\
\hline & & & & 2 & Worst & & 1 & & & & 1 \\
\hline & & & $\begin{array}{ll}\text { Tidak } & \text { Lulus } \\
\text { SMU } & \\
\end{array}$ & ? & Worst & & & & 1 & & 1 \\
\hline & & $\begin{array}{l}1 \\
\text { Tot } \\
\text { al }\end{array}$ & & & & & 2 & 2 & 9 & & 13 \\
\hline & & 2 & $\begin{array}{l}\text { Pindah } \\
\text { Jurusan/Jenjan } \\
\text { g/Renim }\end{array}$ & ? & $\begin{array}{l}\text { F- } \\
\text { Pindah } \\
\text { Jur } \\
\end{array}$ & & & & & 1 & 1 \\
\hline
\end{tabular}




\begin{tabular}{|c|c|c|c|c|c|c|c|c|c|c|}
\hline & & $\begin{array}{l}\text { Terima } \\
\text { UMPTN }\end{array}$ & ? & $\begin{array}{l}\text { F- } \\
\text { UMPT } \\
\text { N }\end{array}$ & 2 & 3 & 1 & & & 6 \\
\hline & & & & Bad- & & & & & & \\
\hline & & Undur Diri & ? & Und & & 1 & 2 & 2 & 1 & 6 \\
\hline & & & & Bad- & & & & & & \\
\hline & & & 1 & Und & & 1 & 2 & 1 & & 4 \\
\hline & & & & Bad- & & & & & & \\
\hline & & & 2 & Und & & & & 1 & & 1 \\
\hline & & & & Bad- & & & & & & \\
\hline & & & 3 & Und & & 1 & & & & 1 \\
\hline & & $\begin{array}{ll}\text { Undur } & \text { Diri }\end{array}$ & & Bad- & & & & & & \\
\hline & & karena DO & 1 & Keu & & & & 1 & & 1 \\
\hline & & $\begin{array}{ll}\text { Undur } & \text { Diri }\end{array}$ & & & & & & & & \\
\hline & & Sepihak dari & & Bad- & & & & & & \\
\hline & & BINUS & 1 & Keu & & & & & 1 & 1 \\
\hline & 2 & & & & & & & & & \\
\hline & Tot & & & & & & & & & \\
\hline & al & & & & 2 & 6 & 5 & 5 & 3 & 21 \\
\hline Komputerisasi & & & & & & & & & & \\
\hline Akuntansi Total & & & & & 2 & 8 & 7 & 14 & 3 & 34 \\
\hline Sistem Informasi & 1 & Diberhentikan & ? & Worst & & 3 & 3 & 3 & & 9 \\
\hline & & Tidak Lulus & & & & & & & & \\
\hline & & SMU & $?$ & Worst & & & 1 & & & 1 \\
\hline & 1 & & & & & & & & & \\
\hline & Tot & & & & & & & & & \\
\hline & al & & & & & 3 & 4 & 3 & & 10 \\
\hline & & Pindah & & F- & & & & & & \\
\hline & & Jurusan/Jenjan & & Pindah & & & & & & \\
\hline & 2 & $\mathrm{~g} /$ Renim & ? & Jur & & & 1 & & & 1 \\
\hline & & & & F- & & & & & & \\
\hline & & Terima & & UMPT & & & & & & \\
\hline & & UMPTN & ? & $\mathrm{N}$ & & 2 & 2 & & & 4 \\
\hline & & & & Bad- & & & & & & \\
\hline & & Undur Diri & ? & Und & 2 & & 3 & 4 & 3 & 12 \\
\hline & & Undur $\quad$ Diri & & Bad- & & & & & & \\
\hline & & karena DO & ? & Keu & & & & 1 & & 1 \\
\hline & 2 & & & & & & & & & \\
\hline & Tot & & & & & & & & & \\
\hline & al & & & & 2 & 2 & 6 & 5 & 3 & 18 \\
\hline Sistem Informasi & & & & & & & & & & \\
\hline Total & & & & & 2 & 5 & 10 & 8 & 3 & 28 \\
\hline Teknik & & & & & & & & & & \\
\hline Informatika & 1 & Diberhentikan & 1 & Worst & & 1 & 2 & 2 & 2 & 7 \\
\hline & & Tidak Lulus & & & & & & & & \\
\hline & & SMU & ? & Worst & & & & 1 & & 1 \\
\hline & 1 & & & & & & & & & \\
\hline & Tot & & & & & & & & & \\
\hline & al & & & & & 1 & 2 & 3 & 2 & 8 \\
\hline & & Pindah & & F- & & & & & & \\
\hline & & Jurusan/Jenjan & & Pindah & & & & & & \\
\hline & 2 & $\mathrm{~g} /$ Renim & ? & Jur & & & & 1 & & 1 \\
\hline & & & & F- & & & & & & \\
\hline & & & & Pindah & & & & & & \\
\hline & & & 1 & Jur & & & 1 & & & 1 \\
\hline & & & & F- & & & & & & \\
\hline & & Terima & & UMPT & & & & & & \\
\hline & & UMPTN & ? & $\mathrm{N}$ & 4 & 17 & & & & 21 \\
\hline & & & & Bad- & & & & & & \\
\hline & & Undur Diri & ? & Und & & 1 & & & 1 & 2 \\
\hline & & & & Bad- & & & & & & \\
\hline & & & 1 & Und & 1 & 4 & 6 & 2 & 1 & 14 \\
\hline & & Undur & 2 & Bad- & & & 1 & & & 1 \\
\hline
\end{tabular}




\begin{tabular}{|c|c|c|c|c|c|c|c|c|c|c|c|c|}
\hline & & & & \multicolumn{2}{|l|}{ karena DO } & \multicolumn{3}{|l|}{ Keu } & \multirow[b]{2}{*}{8} & \multirow[b]{2}{*}{3} & \multirow[b]{2}{*}{2} & \multirow[b]{2}{*}{40} \\
\hline & & & $\begin{array}{l}2 \\
\text { Tot } \\
\text { al }\end{array}$ & & & & 5 & 22 & & & & \\
\hline & & Teknik & & & & & & & & & & \\
\hline & & Informatika Total & & & & & 5 & 23 & 10 & 6 & 4 & 48 \\
\hline & 2 & & & & & & & & & & & \\
\hline & Total & & & & & & 9 & 36 & 27 & 28 & 10 & 110 \\
\hline 2006 & & & & & & & & 14 & 18 & 16 & & \\
\hline Total & & & & & & & 16 & 0 & 8 & 0 & 53 & 557 \\
\hline & & Komputerisasi & & & & & & & & & & \\
\hline 2007 & 1 & Akuntansi & 1 & Diberhentikan & $?$ & Worst & & 1 & & & & 1 \\
\hline & & & & PTTKK & 1 & Worst & & & & & 1 & 1 \\
\hline & & & 1 & & & & & & & & & \\
\hline & & & Tot & & & & & & & & & \\
\hline & & & al & & & & & 1 & & & 1 & 2 \\
\hline & & & & & & F- & & & & & & \\
\hline & & & & Terima & & UMPT & & & & & & \\
\hline & & & 2 & UMPTN & ? & $\mathrm{N}$ & & 1 & & & & 1 \\
\hline & & & & & & Bad- & & & & & & \\
\hline & & & & Undur Diri & ? & Und & & 2 & 3 & & & 5 \\
\hline & & & & & & Bad- & & & & & & \\
\hline & & & & & 1 & Und & & 1 & 2 & & 2 & 5 \\
\hline & & & & Undur $\quad$ Diri & & Bad- & & & & & & \\
\hline & & & & karena DO & 1 & Keu & & & & 1 & & 1 \\
\hline & & & & $\begin{array}{ll}\text { Undur } & \text { Diri }\end{array}$ & & & & & & & & \\
\hline & & & & karena & & Bad- & & & & & & \\
\hline & & & & Keuangan & ? & Keu & & & 1 & 1 & & 2 \\
\hline & & & & Undur $\quad$ Diri & & & & & & & & \\
\hline & & & & Sepihak dari & & Bad- & & & & & & \\
\hline & & & & BINUS & 1 & Keu & & & 2 & & & 2 \\
\hline & & & 2 & & & & & & & & & \\
\hline & & & Tot & & & & & & & & & \\
\hline & & & al & & & & & 4 & 8 & 2 & 2 & 16 \\
\hline & & Komputerisasi & & & & & & & & & & \\
\hline & & Akuntansi Total & & & & & & 5 & 8 & 2 & 3 & 18 \\
\hline & & Sistem Informasi & 1 & Diberhentikan & $?$ & Worst & & & 2 & 1 & & 3 \\
\hline & & & 1 & & & & & & & & & \\
\hline & & & Tot & & & & & & & & & \\
\hline & & & al & & & & & & 2 & 1 & & 3 \\
\hline & & & & Pindah & & F- & & & & & & \\
\hline & & & & Jurusan/Jenjan & & Pindah & & & & & & \\
\hline & & & 2 & g/Renim & ? & Jur & & & 1 & & & 1 \\
\hline & & & & & & F- & & & & & & \\
\hline & & & & Terima & & UMPT & & & & & & \\
\hline & & & & UMPTN & ? & $\mathrm{N}$ & & 5 & 3 & & & 8 \\
\hline & & & & & & Bad- & & & & & & \\
\hline & & & & Undur Diri & ? & Und & & 14 & 16 & 9 & 2 & 41 \\
\hline & & & & Undur $\quad$ Diri & & Bad- & & & & & & \\
\hline & & & & karena DO & ? & Keu & & 2 & 5 & 4 & 1 & 12 \\
\hline & & & & $\begin{array}{ll}\text { Undur } & \text { Diri }\end{array}$ & & & & & & & & \\
\hline & & & & karena & & Bad- & & & & & & \\
\hline & & & & Keuangan & ? & Keu & & 1 & 5 & 3 & 1 & 10 \\
\hline & & & & Undur $\quad$ Diri & & & & & & & & \\
\hline & & & & Sepihak dari & & Bad- & & & & & & \\
\hline & & & & BINUS & $?$ & Keu & & 4 & 14 & 3 & 1 & 22 \\
\hline & & & 2 & & & & & & & & & \\
\hline & & & Tot & & & & & & & & & \\
\hline & & & al & & & & & 26 & 44 & 19 & 5 & 94 \\
\hline & & Sistem Informasi & & & & & & & & & & \\
\hline & & Total & & & & & & 26 & 46 & 20 & 5 & 97 \\
\hline & & Teknik & 1 & Diberhentikan & 1 & Worst & 2 & 2 & 1 & 2 & 1 & 8 \\
\hline
\end{tabular}




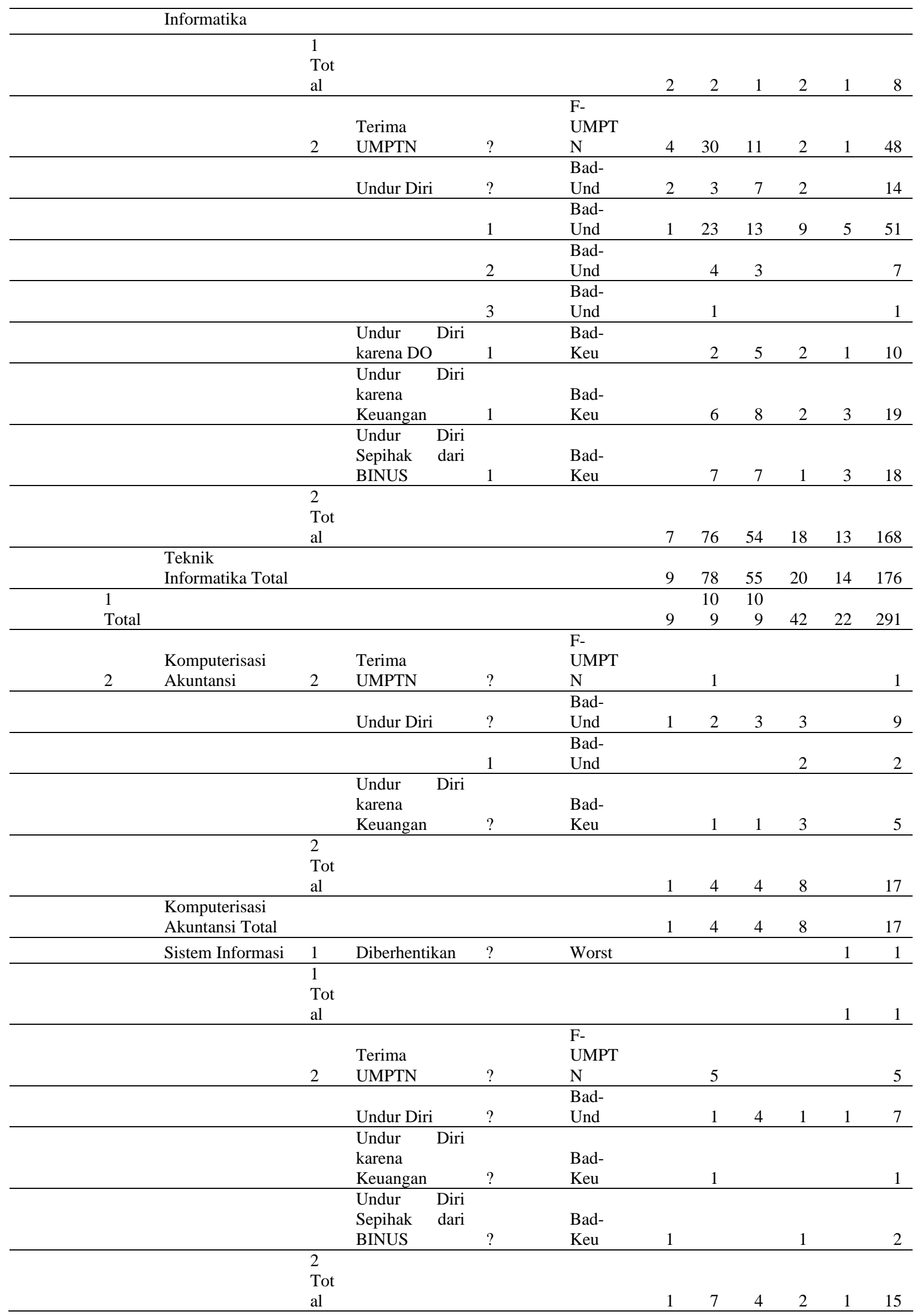




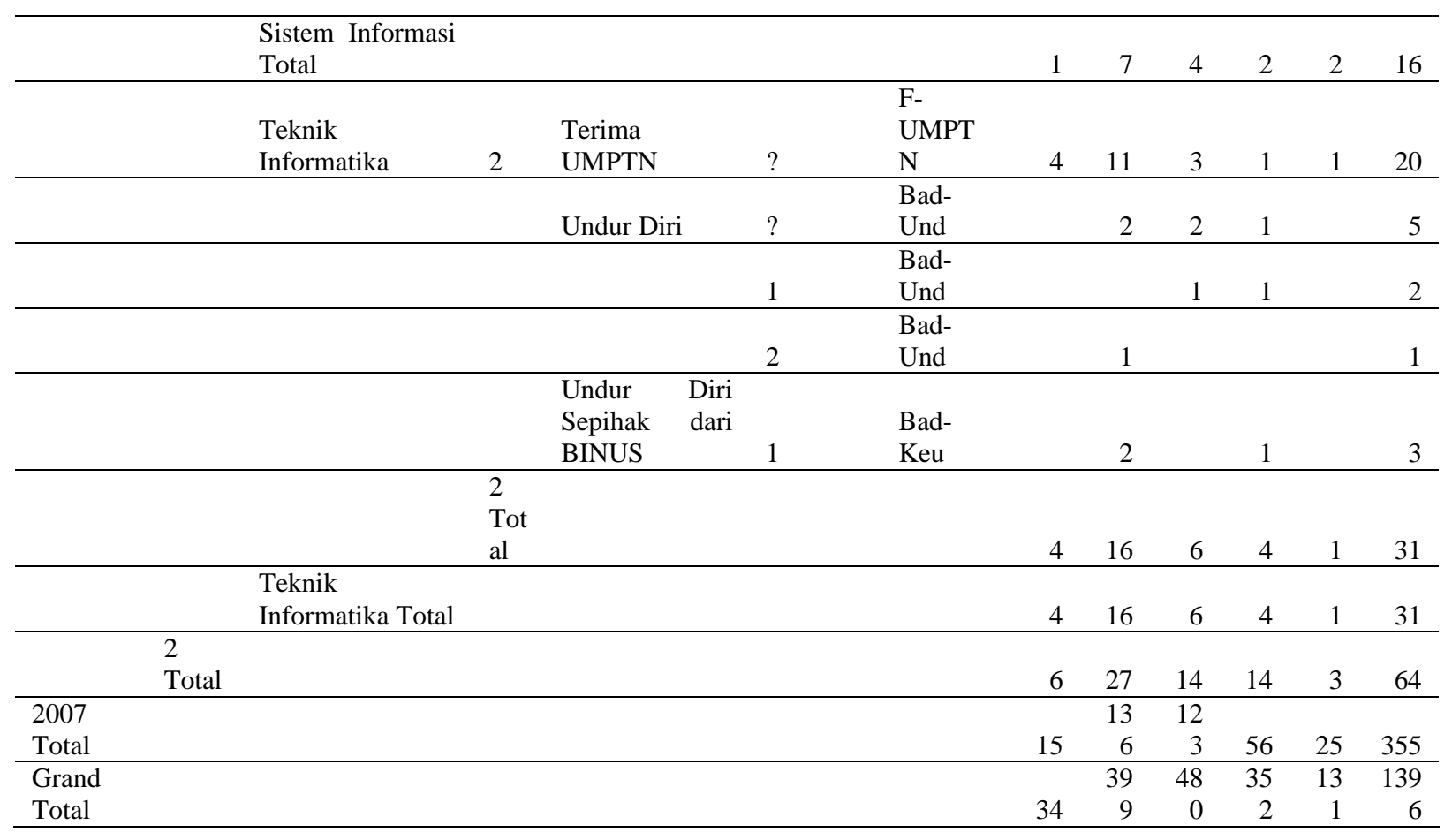

Metode yang digunakan dalam paper ini adalah dengan case study dan analisis menggunakan data mining. Tool yang digunakan untuk analisis data mining ini adalah menggunakan WEKA, di mana data diproses dengan decision tree. Berikut adalah tampilan data yang digunakan (Gambar 3).

\begin{tabular}{|c|c|c|c|c|c|c|c|c|c|c|c|c|c|c|c|c|c|c|c|c|c|c|c|c|}
\hline \multicolumn{23}{|c|}{ - ARFF-Viewer-D:IDR - } & \multicolumn{2}{|c|}{0 - } \\
\hline \multicolumn{25}{|c|}{ File Edit View } \\
\hline \multicolumn{25}{|c|}{ Bi_do_1.csv ${ }^{\prime}$} \\
\hline \multicolumn{25}{|c|}{ ( } \\
\hline No. & $\begin{array}{l}\text { priod } \\
\text { Numeric }\end{array}$ & $\begin{array}{l}\text { jokkel } \\
\text { Numeric }\end{array}$ & \begin{tabular}{|l|l|} 
nimhs \\
Numeric
\end{tabular} & $\begin{array}{l}\text { kdjur } \\
\text { Numeric }\end{array}$ & $\mid \begin{array}{c}\text { mmjur } \\
\text { Nominas }\end{array}$ & \begin{tabular}{|l|} 
jismu \\
Numeric \\
\end{tabular} & \begin{tabular}{|l} 
Jurusan__MMU \\
Nominal
\end{tabular} & $\mid \begin{array}{l}\text { ktsmu } \\
\text { Nominal }\end{array}$ & $\left|\begin{array}{|c|}\text { Grade } \\
\text { Nominat }\end{array}\right|$ & 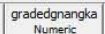 & \begin{tabular}{|l|}
$\begin{array}{l}\text { tipe_smu } \\
\text { Numerci }\end{array}$ \\
\end{tabular} & \begin{tabular}{|c|c|} 
nama_tipe \\
Nominat \\
\end{tabular} & $\mid \begin{array}{l}\text { jenis_smu } \\
\text { Numerc } \\
\text { Nute }\end{array}$ & \begin{tabular}{l|l|} 
unamajenis \\
Nominal
\end{tabular} & \begin{tabular}{|l} 
jnpdf \\
Numeric
\end{tabular} & 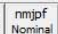 & \begin{tabular}{|l|l|} 
kdkab & nmkab \\
Numeric & Nominal
\end{tabular} & \begin{tabular}{|l|} 
kdpro \\
Numeric \\
\end{tabular} & $\mid$\begin{tabular}{|l|}
$\left|\begin{array}{l}\text { mmpro } \\
\text { Nominal }\end{array}\right|$ \\
$\mid$ |
\end{tabular} & \begin{tabular}{|l|} 
kode \\
Nominal
\end{tabular} & $\mid \begin{array}{c}\text { jenis } \\
\text { Nominal }\end{array}$ & $\left|\begin{array}{l}\text { deskripsi } \\
\text { Nominas }\end{array}\right|$ & \begin{tabular}{|l|} 
kategori \\
Numeric
\end{tabular} & $\begin{array}{l}\text { ketkatego } \\
\text { Nominal }\end{array}$ \\
\hline 227 & $\frac{\text { Numereft }}{2007.0}$ & Numence & Numence & 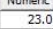 & Kompu... & \begin{tabular}{|l|} 
Nomence \\
120.0
\end{tabular} & SMU JURURS... & Kabs, S... & & 0.0 & \begin{tabular}{|c|c|} 
\\
\end{tabular} & SMA & & . Nostastal & & Pindah.... & $332.0 \mathrm{Kab} . \mathrm{S} . .$. & & Banten D D & & Undur ... & Pengunan... & & Wolumar Diri \\
\hline 428 & 2007.0 & 1.0 & $1.100 \ldots$ & & Teknik... & 110.0 & SMU JURUS.. & KAB.S... & & 0.0 & & SMA & & .0 Swasta & & Pindah.... & 55.0 Kab. S.... & & Jawa & & & & & Undur Dirit \\
\hline & 2007.0 & 1.0 & 1. $1.00 \ldots$ & & Kompu... & 120.0 & SMU JURUS... & JAKAR... D D & & 1.0 & & SMA & & .0 Negeri & & Denda & 4.0 rakart & & DKI Ja... & & PTाKK & Dikelua... & 10 & \\
\hline$\frac{2}{2}$ & 2005.0 & 1.0 & $9.007 \ldots$ & & & & SMU JuRUS: & (JAKAR, & & 200 & & SMA & & oswasta & & Denda & 20.0kakat... & & DKJ Ja.... & & Pindah... & Pindal. & 200 & Undur Diri \\
\hline$\frac{2}{3}$ & 2006.0 & 1.0 & $1.000 \ldots$ & & Right click & k (or left + & falt for conter & t tmenul. & & 2.0 & & SMA & & .0 Swasta & 10.0 & Penda.. & 1.0 Jakart... & & DKI Ja... & & Pindah.... & Pindah ... & & Undur Diri \\
\hline 4 & 2006.0 & 2.0 & $1.000 \ldots$ & & Kompu... & 120.0 & SMU JURUS... & JAKAR... & & $\frac{2.0}{1.0}$ & 1.0 & & & .0 Swasta & 10.0 & Penda.. & 1.0 Jakart... & & DKI Ja.... & & Pindah.... & Pindah $\ldots$ & & Undur Dirit \\
\hline 5 & 2006.0 & 2.0 & $1.000 \ldots$ & & Teknik... & 110.0 & SMU JURUS... & JAKAR.... & & 2.0 & & & & .0 Swasta & 10.0 & Penda. & 4.0 Jakart... & & OKI Ja... B & & Pindah... & Pindah ... & & Undur Diri \\
\hline 6 & 2005.0 & 1.0 & $9.008 \ldots$ & & Tekriki... & 110.0 & SMU JURUS... & КАBT... & & 3.0 & & & & .0 Swasta & & Penda. & 335.0 Kab. T... & & Banten $B$ & & Pindah.... & Pindah ... & & Undur Diri \\
\hline & 2005.0 & 1.0 & $9.008 .$. & & TTeknik... & 110.0 & SMU JURUS... & JAKAR... A & & 4.0 & & & & .0 Swasta & & Penda.. & 1.0 Jakart... & & DKI Ja... B & & Pindah... & Pindah. & & Undur Diri \\
\hline 8 & 2006.0 & 2.0 & $1.000 \ldots$ & & Treknik.. & 110.0 & SMU JURUS... & TANUU.... B & & 3.0 & 1.0 & & & .0 Swasta & & Penda. & 346.0 Kota $T \ldots$ & & Kepula... B & & Pindah... & Pindah ... & & Undur Diri \\
\hline & 2005.0 & 1.0 & $9.008 \ldots$ & & Teknik... & 110.0 & SMU JURUS... & JAKAR...A A & & 4.0 & & & & & & Penda.. & 2.0 Jakart... & & ok Ja...c & & Drop ... & Do kar... & & Berhenti \\
\hline 10 & 2005.0 & 1.0 & $9.007 \ldots$ & & Kомmpu.. & 120.0 & SMU JURUS... & JAKAR...D & & 1.0 & 1.0 & SMA & & .0 Swasta & & Penda.. & 3.0 Jakart... & & OKI Ja... & & Drop ... & Do kar... & & Berhenti \\
\hline 11 & 2005.0 & 1.0 & $9.008 \ldots$ & & Teknik... & 110.0 & SMU JURUS... & Kota J... D & & 1.0 & & & & & & Penda. & 167.0 Kota J... & & Jambi & & Drop... & Do kar. & & Berhenti \\
\hline 12 & 2005.0 & 1.0 & $9.008 .$. & & Teknik... & 110.0 & SMU JURUS... & Kota P... B & & 3.0 & 1.0 & & & .0 Swasta & 10.0 & Penda.. & 121.0 Kota $\mathrm{P} \ldots$ & & Sumat... c & & Drop ... & Do kar... & & Berhenti \\
\hline 13 & 2005.0 & 1.0 & 9.008... & & J Teknik... & 110.0 & S SMU JURUS:.. & JAKAR...B & & 3.0 & & & & . 0 Negeri & & DPenda.. & 3.0 J zakart... & & IDKI Ja...c & & Drop ... & Dokar... & & j:Berhenti \\
\hline 14 & 2005.0 & 2.0 & $9.008 .$. & 24.0 & Teknik... & 110.0 & SMU JURUS... & JAKAR...C & & 2.0 & 1.0 & SMA & & .0 Swasta & & Penda.. & 1.0 Jakart... & & oKI Ja.... & & Drop ... & Do kar.... & & Berhenti \\
\hline 15 & 2005.0 & 1.0 & 9.008. & 24.0 & Teknik... & 110.0 & SMU JURUS... & KAB. S...D & & 1.0 & & & & & & Penda. & $327.0 \mathrm{Kab} . \mathrm{S} . .$. & & |rian J... & & Drop ... & Do kar... & & \\
\hline 16 & 2005.0 & 1.0 & 9.008. & & Kompu... & 110.0 & SMU JURUS... & KAB. B...C & & 2.0 & 1.0 & SMA & & .0 Swasta & & Penda. & 27.0 Kab. B... & & Jawa ... & & Drop... & Do kar... & & Berhenti \\
\hline$\frac{17}{18}$ & 2005.0 & 1.0 & $9.008 .$. & 23.0 & Kompu.... & 120.0 & SMU JURUS... & KAB, B... B & & 3.0 & 1.0 & SMA & & . 0 Swasta & & Penda. & 159.0 Kab. B... & & Riau & & Drop... & Do kar... & & Berhenti \\
\hline$\frac{18}{19}$ & $\begin{array}{l}2005.0 \\
2055.0\end{array}$ & $\begin{array}{l}1.0 \\
1.0\end{array}$ & $9.008 . .$. & $\frac{23.0}{23.0}$ & Kompu.... & $\begin{array}{l}120.0 \\
1200\end{array}$ & SMU JURUS... & JAKAR.... B & s & 3.0 & & & & . 0 .05wasta & & Penda., & 3.0 Jakart... & & OKK Ja... & & Drop ... & Do kar... & & DBerhenti \\
\hline 20 & 2005.0 & $\begin{array}{l}1.0 \\
1.0\end{array}$ & $\begin{array}{l}9.008 . \ldots \\
9.008 . . .\end{array}$ & & Tompouvi... & $\begin{aligned} \frac{1200 .}{120} \\
110.0\end{aligned}$ & SMUU JURUS... & $\begin{array}{l}\text { Kotat T.... } \\
\text { KOTA... }\end{array}$ & & 2.0 & & & & & & & $\begin{array}{l}330.0 \text { Kotat T... } \\
\text { 30. Ko Kota } \ldots\end{array}$ & & Banten & & & Do kar... & & Berhenti \\
\hline 21 & 2005.0 & 1.0 & $9.008 \ldots$ & & Teknik... & 110.0 & SMU JURUS... & JAKAR,... B & & 3.0 & & SMA & & ONegeri & & & 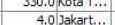 & & $\begin{array}{l}\text { Banten } \\
\text { Dok ya. }\end{array}$ & & & Do kar. & & Berhenti \\
\hline 22 & 2005.0 & 1.0 & 9.008... & & & 120.0 & SMU JURUS... & KAB, L...C & & 2.0 & & & & .0 Swasta & & & 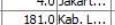 & & STKumat... & & & DO kar. & & Berhent \\
\hline 23 & 2005.0 & & $\begin{array}{ll}9.008 . . \\
\end{array}$ & & Teknik... & 110.0 & SMU JURUS... & JAKAR,... A & & 4.0 & 1.0 & & & .0 Swasta & & & 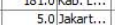 & & DKT Ja... & & Drop. & DO kar. & & Berhent \\
\hline 24 & 2005.0 & 1.0 & $9.008 .$. & & TTeknik... & & & JAKAR...C C & & 2.0 & & & & .0 Swasta & & & 4.0 Jakart... & & DKI Ja... & & Drop. & Do kar. & & OEerinent \\
\hline 25 & 2005.0 & & $9.008 .$. & & Kompu.. & & & JAKAR.... B & & 3.0 & & & & .0 Swasta & & & 4.0 Jakart.. & & DKI Ja... & & Drop & Do kar... & & Gerinent \\
\hline 26 & 2005.0 & & $\begin{array}{l}9.008 \ldots \\
\end{array}$ & & Teknik... & & & TFEIT ... A A & & 4.0 & & & & .0 Swasta & & & 119.0 Kot & & Sumat. & & Drop. & Do kar. & & SBentent \\
\hline 27 & 2005.0 & 2.0 & $\begin{array}{l}9.007 . . \\
\end{array}$ & & Kотрuн... & & & JAKAR.... C & & 2.0 & & & & .0 Swasta & & & & & DKT Ta. & & Dorop.... & Dokar. & & Detrinent \\
\hline 28 & 2005.0 & 1.0 & 9.008. & & Kompu... & 12 & SSMU] & Kab, T,..A $A$ & & 4.0 & & & & .0 Swasta & & Penda. & $335.0 \mathrm{ke}$ & & Banten & & Droo. & Do & & \\
\hline 29 & 2005.0 & 1.0 & 9.00 & & Trek & & & & & 2.0 & & & & .0 Swasta & & & & & & & & & & \\
\hline 30 & 2005.0 & 1.0 & 9.008 & 24.0 & Trek & & & KAB & & 2.0 & & SMA & & .0 Swasta & & & & & & & & & & \\
\hline & 2005.0 & 1.0 & 9.008 & & Tiekr & & MU & JAKAR... B & B & 3.0 & & SMA & & 0 Negeri & & Denda & & & DKI Ja... & & & DO & & Oerenents \\
\hline 32 & 2005.0 & 20 & 9.008. & 24.0 & Trekr & 1100 & SMUU J URUS... & Kota $T_{\ldots, A}$ & A & 4.0 & & SMA & & 0 S swasta & & & 330.0 Kota T. & & Banten & & Droo. & Dokar. & & Berhenti \\
\hline 33 & 2005.0 & 1.0 & $9.008 .$. & 24.0 & Teknik.. & 110,0 & SMU UUR & JAKAR . & B & 3.0 & & & & & & Denda. & 4.0 lakart. & & DKK Ja... & & Droo. & Do kar... & & OBerhenti \\
\hline 34 & 2005.0 & 1.0 & $9.008 . .$. & 23.0 & KKomoü... & 120.0 & SMU JURUS... & $K A B, K \ldots C$ & c & 2.0 & & SMA & & .0 Swasta & 10.0 & Penda. & $26.0 \mathrm{Kab}, \mathrm{K}$ & & Jawa.... & & Droo. & Dokar. & & Berhenti \\
\hline 35 & 2005.0 & 1.0 & $9.008 . .$. & 24.0 & Trekrik... & 250.0 & STM LISTRIK. & JAKAR... D D & o & 1.0 & & SMA & & .0 Swasta & & Denda.. & 5.0 Jakart... & & OKK Ja... & & Drop... & Do kar... & & Berhenti \\
\hline 36 & 2005.0 & 2.0 & $9.008 . .$. & 23.0 & KKompu... & 120.0 & SMMU JURUS... & Kab, B...c & c & 2.0 & & SMA & & .05 wasta & & Penda.. & $337.0 \mathrm{kab}, \mathrm{B.} \ldots$ & & Kepula.... & & Drop. & Do kar.. & & Berhenti \\
\hline 37 & 2005.0 & 1.0 & $9.008 \ldots$ & & Tieknik... & 110.0 & SMU JURUS... & JAKAR...A & & 4.0 & & & & .0 Swasta & & Penda.. & 4.0 Jakart... & & oKI Ja... & & Drop.. & Do kar. & & Berhenti \\
\hline & monent & & a nne & $74 n$ & & $11 n n$ & Alaminiolis & & & $2 n$ & & & & nlemarerts & & Doands & 270 nknts & tont & Acritam & & nimm & manger & & Naonthenti, \\
\hline
\end{tabular}

Gambar 3. Daftar data yang digunakan. 


\section{HASIL DAN PEMBAHASAN}

Dari data pada Gambar 3 dipilih attribute (9 attribute) untuk melakukan analisis terhadap jenis kategori undur diri yang ada. Data diproses dengan menggunakan aplikasi WEKA dengan melakukan klasifikasi terhadap data tersebut. Attribute yang digunakan adalah Jenis Kelamin, Jenis Pendaftaran, Jurusan yang diminati, Jurusan SMA, Propinsi Asal, Nilai Algoritma (semester awal), Kategori Undur Diri, Grade Hasil tes Masuk dan Kelas dari Jenis undur diri tersebut. Data diproses dengan pilihan Tree dan jenis J48 dengan cross-validation 10 Fold.

Hasil running melalui aplikasi WEKA dapat dilihat dari data di bawah ini:

$===$ Run information $===$

Scheme:weka.classifiers.trees.J48 -C 0.25 -M 2

Relation:

DO_2-weka.filters.unsupervised.attribute.Reorder-

R1,2,3,4,5,6,7,8,9,10,11,12,13,14,15,16,17,18,19,20,21,22,23,24,25,26,27,28,29,30,31,32,33,34,35-

weka.filters.unsupervised.attribute.Remove-R1,3-5,7,9-10,12-20,22-24,26-28,30-33

Instances: 1396

Attributes: 9

jnkel

nmjur

Jurusan_SMU

gradedgnangka

nmjpf

nmpro

kategori

grade_mtk_algo

class

Test mode:10-fold cross-validation

$===$ Classifier model (full training set) $===$

J48 pruned tree

kategori $<=1$ : Worst (463.0)

kategori $>1$

| gradedgnangka $<=3$

| | gradedgnangka $<=0$

| | | nmjur = Komputerisasi Akuntansi: F-UMPTN (3.0/1.0)

| | | nmjur = Teknik Informatika: F-UMPTN (25.0/6.0)

| | | nmjur = Sistem Informasi: Bad-Und (3.0/1.0)

| gradedgnangka > 0: Bad-Und (578.0/224.0)

gradedgnangka $>3$

| | nmpro = DKI Jakarta

｜｜Ｊurusan_SMU = SMU JURUSAN IPS

| | | | nmjur = Komputerisasi Akuntansi: Bad-Und (13.0/1.0)

| | | | nmjur = Teknik Informatika: Bad-Und (0.0)

| | | | nmjur = Sistem Informasi: F-UMPTN (24.0/15.0)

| | | Jurusan_SMU = SMU JURUSAN IPA: F-UMPTN (165.0/73.0) 


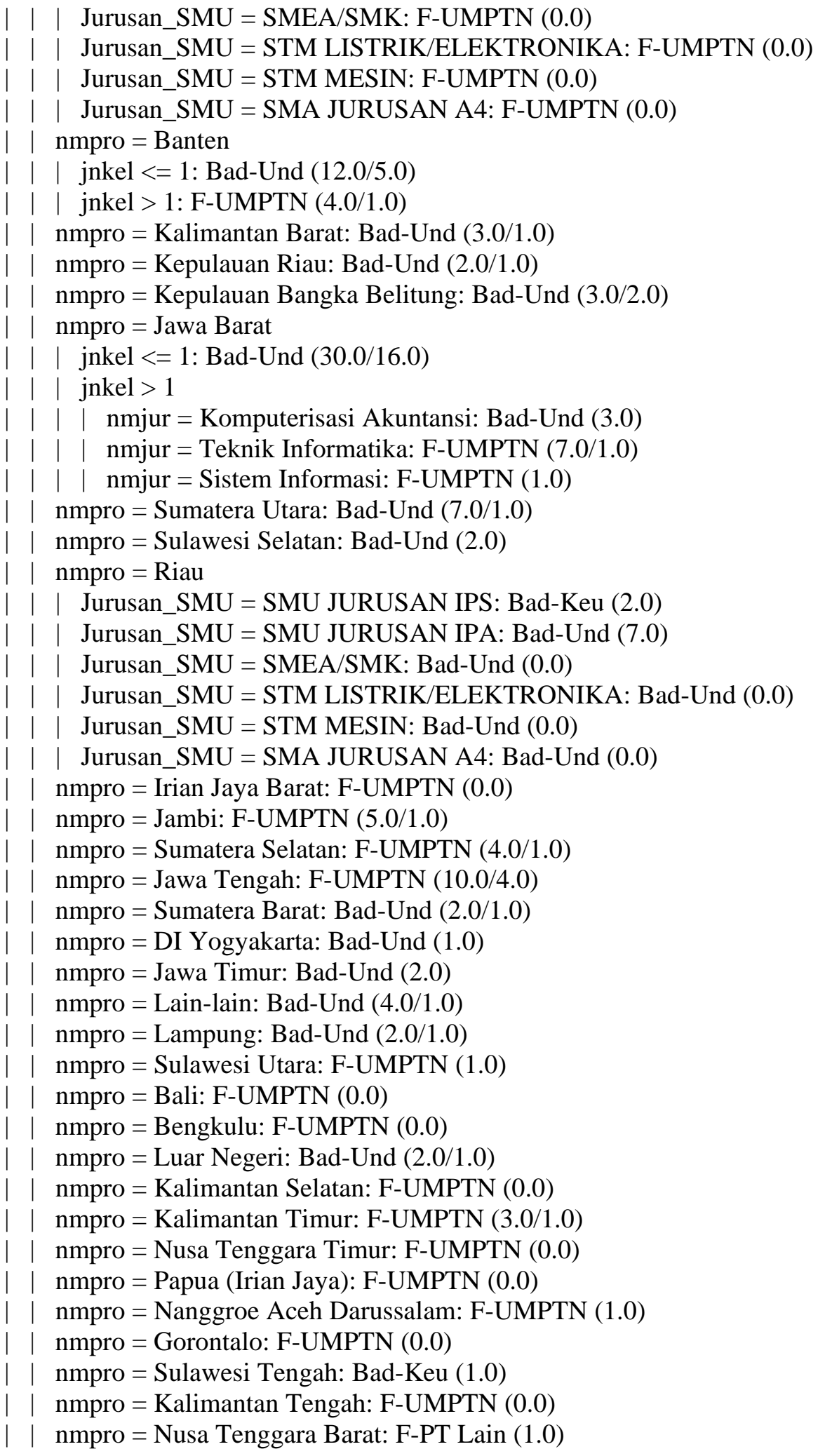

Number of Leaves : $\quad 52$

Size of the tree: $\quad 63$

Time taken to build model: 0.05 seconds

$===$ Stratified cross-validation $===$ 
$===$ Summary $==$

Correctly Classified Instances $\quad 996 \quad 71.3467 \%$

Incorrectly Classified Instances $\quad 400 \quad 28.6533 \%$

Kappa statistic $\quad 0.5848$

Mean absolute error

0.1221

Root mean squared error

Relative absolute error

0.2524

$51.0743 \%$

$73.0225 \%$

Root relative squared error

1396

$===$ Detailed Accuracy By Class $===$

\begin{tabular}{llllllll} 
TP Rate & FP Rate & Precision & \multicolumn{3}{c}{ Recall F-Measure ROC Area Class } \\
1 & 0 & 1 & 1 & 1 & 1 & Worst \\
0 & 0 & 0 & 0 & 0 & 0.702 & F-PindahJur \\
0.792 & 0.294 & 0.601 & 0.792 & 0.683 & 0.8 Bad-Und \\
0 & 0.008 & 0 & 0 & 0 & 0.752 & Bad-Keu \\
0 & 0 & 0 & 0 & 0 & 0.56 & F-PT Lain \\
0.623 & 0.109 & 0.517 & 0.623 & 0.565 & 0.833 & F-UMPTN \\
. & 0.713 & 0.123 & 0.628 & 0.713 & 0.665 & 0.863
\end{tabular}

$\begin{array}{lllllll}\text { Weighted Avg. } & 0.713 & 0.123 & 0.628 & 0.713 & 0.665 & 0.863\end{array}$

$===$ Confusion Matrix $===$

a b c d e $\mathrm{f}<-$ - classified as

\begin{tabular}{llllll|l}
463 & 0 & 0 & 0 & 0 & 0 & $\mathrm{a}=$ Worst
\end{tabular}

\begin{tabular}{llllll|l}
0 & 0 & 10 & 0 & 0 & $1 \mid$ & $\mathrm{b}=$ F-PindahJur
\end{tabular}

\begin{tabular}{llllll|l}
0 & 0 & 396 & 5 & 0 & $99 \mid \mathrm{c}=$ Bad-Und
\end{tabular}

\begin{tabular}{llllll|l}
0 & 0 & 173 & 0 & 0 & 25 & $\mathrm{~d}=$ Bad-Keu
\end{tabular}

\begin{tabular}{llllll|l}
0 & 0 & 1 & 0 & 0 & 3 & $\mathrm{e}=\mathrm{F}-\mathrm{PT}$ Lain
\end{tabular}

\begin{tabular}{llllll|l}
0 & 0 & 79 & 4 & 0 & 137 & $\mathrm{f}=\mathrm{F}-\mathrm{UMPTN}$
\end{tabular}

Tree Visualization dari proses tersebut dapat terlihat di bawah ini (Gambar 4), tapi tidak semua ditampilkan.

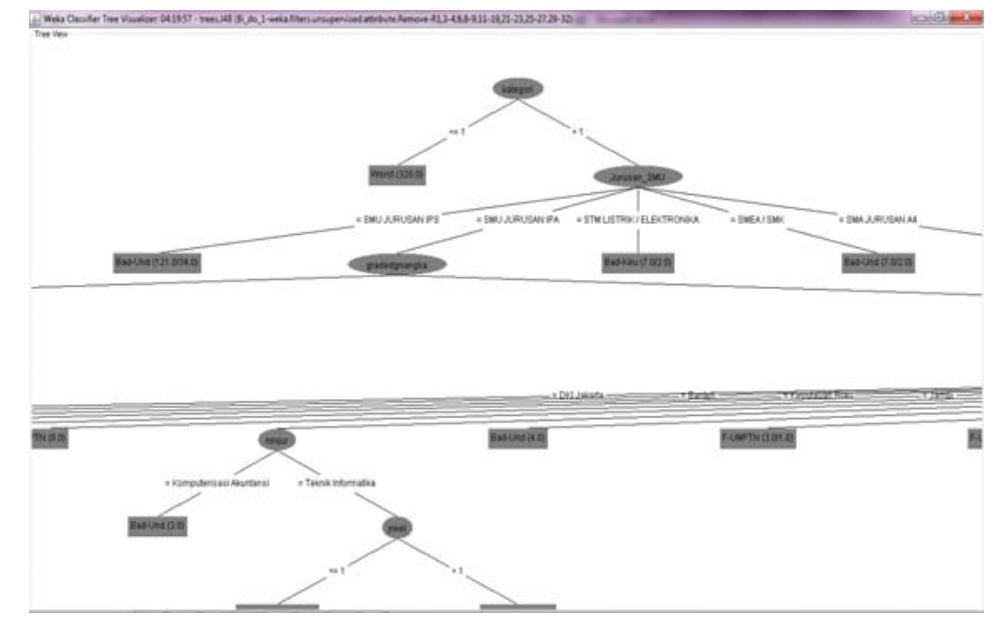

Gambar 4. Tree Visualization. 
Dari hasil proses menggunakan aplikasi WEKA terhadap data tersebut, dapat diambil beberapa hal antara lain: dengan menggunakan J48, angkanya menunjukkan untuk Correctly Classified Instances $=996(71.3467 \%)$ dan Incorrectly Classified Instances= $400(28.6533 \%)$. Angka false positif nya juga rendah. Dengan menggunakan Tree-J48, Kategori undur diri ditentukan oleh parameter antara lain: Jurusan SMA, Grade Tes Masuk, Propinsi, Jurusan yang dipilih dan Jenis Kelamin. Dari data hasil analisis dengan Tree-J48 melalui aplikasi WEKA, dapat diklasifikasikan sebagai berikut.

Untuk kategori Undur diri (1) yaitu Diberhentikan, Drop Out (DO), PTTKK, Tidak Lulus SMU tidak ada variabel yang mempengaruhi. Sedangkan untuk Kategori undur diri lainnya (2), dan dengan grade test masuk bukan grade A dan gradenya kosong dan jurusan Tekink Informasikan mempunyai nilai terbanyak karena lulus UMPTN. Kategori 2 (undur diri) dan gradenya bukan grade A dan grade berada di antara B, C dan D mempunyai nilai undur diri yang cukup banyak. Untuk kategori 2 (undur diri) dan grade test masuknya adalah Grade A, dan propinsinya berasal dari Jakarta serta Jurusan SMAnya IPS dengan pilihan jurusan di binus adalah Komputerisasi Akuntansi dan Teknik Informatika mempunyai jumlah undur diri karena diterima di perguruan tinggi Negeri dan benar-benar mengundurkan diri. Sedangkan untuk Jurusan IPA untuk kategori ini pengunduran diri disebabkan oleh banyaknya yang diterima di perguruan tinggi Negeri. Jika dianalisis berdasarkan propinsi, DKI Jakarta mempunyai jumlah tertinggi disusul Banten. Tetapi jika dilihat dari propinsi diluar JABODETABEK, jumlah tertinggi adalah Sumatra Utara, Riau dan Jawa Tengah. Dengan model ini, dapat diperkirakan (diprediksi) tingkat undur diri dari mahasiswa dengan berbagai kategori undur diri, jika diberikan attribut-attribut seperti yang ditunjukkan oleh perhitungan di atas.

\section{PENUTUP}

Dari hasil analisis proses yang dilakukan dapat dijelaskan bahwa undur diri yang dilakukan mahasiswa terkait dengan beberapa parameter/attribute antara lain Jurusan SMA, Grade Tes Masuk, Propinsi, Jurusan yang dipilih dan Jenis Kelamin. Dari data di atas dapat diprediksi jumlah undur diri dan kategorinya sesuai dengan proses yang telah dilakukan dengan menggunakan data mining dari parameter tersebut. Prediksi dapat dilakukan terhadap data sesungguhnya dari proses yang berjalan. Proses analisis ini hanya menggunakan beberapa parameter/attribut, untuk analisis yang lebih lengkap, dapat ditambahkan parameter-parameter lainnya yang dapat mendukung keakuratan proses analisis misalnya nilai ujian Nasional, tingkat penghasilan orang tua, pekerjaan orang tua dan sebagainya.

\section{DAFTAR PUSTAKA}

Akintola K.G., Adetunmbi A.O., Adeola O.S. (2011). Building data warehousing and data mining from course management systems: a case study of futa course management information systems. International Journal of Database Theory and Application 4(3).

Inmon, W. H.(2005). Building the Data Warehouse (4th edition). New Jersey: John Wiley and Sons.

Kantardzic, Mehmet. (2003). Data Mining: Concepts, Models, Methods, and Algorithms. New Jersey: IEEE Press.

Neary, R. (1999). Building a data warehouse and data mining for a strategic advantage. Journal of Information Technology Theory and Application (JITTA), 1(1), 7 - 21. 